\title{
Assessment of Information Literacy Competency of Management Science Students at the University of Ilorin, Kwara State, Nigeria
}

\author{
Adeyinka Tella ${ }^{1^{*}}$, Rukayat Amadu ${ }^{2}$, Oluwakemi Titilola Olaniyi ${ }^{3}$, Segun Sunday Bamidele ${ }^{4}$ \\ University of llorin and University of South Africa, Nigeria \\ ${ }^{2}$ Department of Library and Information Science, University of Ilorin, Nigeria \\ ${ }^{3}$ Federal College of Education, Technical, Akoka, Lagos, Nigeria \\ ${ }^{4}$ Kwara State College of Education, Ilorin, Kwara State, Nigeria \\ ORCID: A. Tella (0000-0002-5382-4471), R. Amadu (0000-0003-2403-9498), O.T. Olaniyi (0000-0003-1388-6819), S.S. Bamidele(0000-0002-7795-5740)
}

\begin{abstract}
s
The study examined the information literacy (IL) competencies of management science students at the University of llorin, Nigeria. A survey research design was adopted. Data was collected through a questionnaire developed by the authors. A total of 337 randomly selected undergraduate students from six departments represent the sample for the study. Six research questions were developed and answered. The findings demonstrate that respondents generally perceived information literacy IL as an insight on how to effectively and efficiently access and select needed information and as a tool for long-life learning. Respondents have high IL skills in the use of the internet to access information needed in their field and can assess such information from various sources. Competence in the circulation of information, identifying and locating information, and accessing sources and evaluating information are the areas of strength revealed in the study; while the weaknesses identified are inability to determine when information is needed, none awareness of specific search engines. The results also reveal that respondents can use IL skills to retrieve information, search the library, and use specific search terms. Prominent information literacy courses offered are the use of libraries, introduction to computers, and IL training on the use of popular search engines such as Google and Ask Me. The common factors confronting the teaching of IL are power supply, high cost of computers, and limited time available for IL practical and hands-on.
\end{abstract}

Keywords: Information literacy, Information literacy skills, management Science, Undergraduate students, University of Ilorin, Nigeria

\section{INTRODUCTION}

ALA (2007) defined information literacy as "a set of abilities which enable individuals to recognize when information is needed and possess the ability to locate, evaluate, and utilize the needed information." The importance of information literacy in the modern environment of rapid technological change and proliferating information resources cannot be over-emphasized. Because of technological advancement which has resulted in the proliferation of information, individuals are faced with diverse, abundant information choices whether in their academic studies, in the workplace, and their personal lives. Increasingly, information comes to individuals in unfiltered formats, raising questions about its authenticity, validity, and reliability. These pose new challenges for individuals in evaluating and understanding it.

Information literacy is a necessary skill that is utilitari-

*Yazışma Adresi / Address for Correspondence:

A. Tella, Email: tellayinkaedu@yahoo.com

Geliş Tarihi / Received Date: 31.08 .2020

Kabul Tarihi / Accepted Date: 14.06.2021

Doi: $10.26701 /$ uad.788342 an in every aspect of a person's life. Information Literacy (IL) is a set of abilities requiring individuals to recognize when information is needed and can locate, evaluate, and use effectively the needed information. The term Information Literacy first appeared in print in a 1974 report by G. Zurkowski written on behalf of a National Commission on Libraries and Information Science. Zurkowski used the phrase to describe the technique and skill learned by the information literate 'for utilizing a wide range of information tools as well as primary sources in molding solutions to their problem' and draws a relative line between the 'literate' and 'information-literate'. In higher education, most experts agree that information literacy skills play an important role in the overall education of students, both in their learning process and in subsequent practice.

In the words of Lupton (2004, p.24), "information literacy is a way of learning through engaging with information. It includes 'library research skills' and 'IT literacy' but it is broader than these. Information literacy is not just about finding, using, and presenting information, it is about higher-order analysis, synthesis, critical thinking, and problem-solving. It involves seeking and using 
information for independent learning, lifelong learning, participative citizenship, and social responsibility". The United States' American Library Association in a National Forum on Information Literacy Report (1989) defined information literacy as the ability to know when there is a need for information, to be able to identify, locate, evaluate, and effectively use that information for the issue or problem at hand. In the same way: Information literacy competencies can be seen as generic skills, consistent across disciplines or specific skills within a disciplinary lens. The standards themselves use both the language of universality and discipline specificity. It is essential to have an active and continuing program of library orientation and instruction in accessing information developed collaboratively and supported actively by faculty, librarians, academicians, and other information providers. While the best way to achieve information literacy competency for students is through collaboration between disciplinary faculty and librarians, collaboration is not always seen in all situations.

The need for effective functioning in the knowledge society, and to cope with continuous social, economic, and technological changes, has caused a wide debate about what competencies young people and adults need for a successful life and work in the $21^{\text {st }}$ century. Competencies have been defined and selected from the vantage of their contribution to sustainable development, social welfare, cohesion, and justice, as well as personal well-being (OECD, 2005). The European Council and the European Parliament adopted, at the end of 2006, a European framework for developing key competences for lifelong learning. The Framework identifies and defines, for the first time at the European level, the key competences that citizens require for their personal fulfilment, social inclusion, active citizenship and employability in our knowledge-based society. The framework includes competences in 'traditional' subjects, such as mother tongue literacy, numeracy, and knowledge of foreign languages, science, and technology. But it also covers other competencies, such as learning to learn, digital competence, social and civic competences, initiative-taking, entrepreneurship, cultural awareness, and self-expression (European Commission, 2007).

Information literacy competence is a crucial skill in the pursuit of knowledge. For students, information literacy skills would enable students to be independent and student-centric learning, rather than depending on teachers or lecturers to provide answers to questions or problems that they encounter. This, in turn, creates a greater responsibility toward their learning and helps the students become dynamic learners and thinkers, creative, analytical and efficient in the use of information.

In a world where a huge amount of information is available, students need to develop a greater understanding of the source of information and abilities to acquire, evalu- ate, use, and communicate information. In terms of benefits to the students, information literacy enables learners to master content and extend their investigations, become more self-directed, and assume greater control over their learning. With information literacy, the students can turn to individuals who can determine the extent of information needed; access the needed information effectively, and efficiently; evaluate information and its sources critically; incorporate selected information into one's knowledge base; use information effectively to accomplish a specific purpose; understand the economic, legal, and social issues surrounding the use of information, and access, and use information ethically and legally (American Library Association, 2000).

Being information literate will provide the essential skills needed to become a more proficient learner in the university, and subsequently benefit students in both professional and personal endeavors. Information literate individuals who are knowledgeable about finding, evaluating, analyzing, integrating, managing, and conveying information to others efficiently and effectively are more respected. They are students who are most successful at solving problems, providing solutions, and producing new ideas and direction for the future. Information literacy is a repertoire of understandings, practices, and dispositions focused on flexible engagement with the information ecosystem, underpinned by critical self-reflection. The repertoire involves finding, evaluating, interpreting, managing, and using the information to answer questions and develop new ones; and creating new knowledge through ethical participation in communities of learning, scholarship, and practice.(Association of College and Research Library, 2014)

Regardless of the perspective from which information literacy is defined, it is clear that IL is a topic of importance, particularly at the university level. IL is an important concept both at a national as well as international level. There have been various efforts at improving IL across all educational levels beginning from K-12 schools through higher education and also involved the community as awhole. The roots of IL are deeply embedded in the library field and were initiated by librarians, it is important that IL is developed and maintained within the field, but also bereflected upon across all disciplines in academia. Interdisciplinary work in this area is a must for its growth and sustainability Since, IL is needed by all categories of students irrespective of disciplines, it is important therefore to advance research on discipline focused IL skills and competency among undergraduate students.

Faculty of Management Studies at the University of Ilorin, Nigeria is a relatively new faculty. The faculty just graduate from her first set of students in the 2018/19 academic session. Before this time until now, there has not been any study that focused on the information literacy 
skills of this category of students. Besides, where there available some studies at the University of Ilorin, that focus on IL of undergraduates from other faculty, a study that focuses specifically on the Management students is lacking. In light of this and being a very new faculty, it is important to know their information literacy competencies to identify whether or not their IL competencies can match up with undergraduates from other faculties in the university and to know whether more efforts should be intensified in the teaching of IL to the Management students so that they match up with their colleagues in other faculties. It is against this background that the study examined information literacy competency among management science students at the University of Ilorin, Ilorin, Kwara State, Nigeria. The study is significant because it will assist to expose the strategies students adopt in carrying out these assignments, using various competencies, including those of IL; identify the already acquired skill by the students and the ones that need to be added by students to become competent in their quest for information; help the university management to determine the necessary information literary courses that need to be added to the curriculum, and the findings of the study will constitute a useful addition to the body of knowledge in the area of IL in general.

\section{Statement of the Problem}

Undergraduate students in academic institutions are faced with the daunting task of searching for information. They are faced with the challenges of finding information using various traditional and more advanced technological media. It is also observed that the majority of undergraduates are using search engines, wikis, and social media tools to finding formation. The experience of challenges by undergraduate students in search for information is a reflection that students are not receiving adequate instruction in developing the information literacy skills and competencies required to conduct research using credible and viable resources.

In this era of digital transformation, undergraduates are expected to possess some information literacy skills that should enable them to cope effectively since most academic activities in school now involve the use of information communication technologies such as computers and the internet. Information literacy is being taught in various universities for the undergraduates to develop several skills and competencies that will be useful for them throughout their study in the university, and even beyond. However, while many studies are available on information literacy competencies of undergraduate students from the advanced countries, limited studies on the same subject is available in Nigeria. There seems to be limited or no studies that focused on information literacy competencies of the undergraduates especially those in the management sciences. Available studies focused on other information literacy contents and not competencies. It is in light of this that this study examines the information literacy competence of management science students at the University of Ilorin, Kwara State, Nigeria.

\section{OBJECTIVES OF THE STUDY}

The broad objective of this study was to examine information literacy competency among management science students at the University of Ilorin, Kwara State, Nigeria. The specific objectives of the study were to:

1.identify the perception of management science students on information literacy,

2. determine the competency levels of information literacy among management science students,

3.identify the areas of strength and weakness in information literacy competencies among the management science students,

4. examine the extent to which the management science students use their information literacy skills/ competencies in retrieving relevant information;

5. determine the information literacy programs/courses the management science students have offered; and

6.identify the challenges of information literacy competencies being experienced by the management science students.

\section{LITERATURE REVIEW}

Information literacy implies conscious and systematic attention to developing the capacity to define effectively an information need, use research tools and processes to identify and locate such information, assess it, and communicate analysis and synthesis of the information in response to that need. Ojedokun (2007) highlighted the challenges before African higher institutions in producing graduates with relevant skills to function effectively. For students to effectively search, retrieve, evaluate, and use information efficiently to engage in independent learning, research, and life-long learning, IL competence becomes inevitable. Regarding approaches employed some institutions teach Information literacy (IL) as a stand-alone course while others teach it as an embedded course.

According to the Council of Australian University Librarians (2004), information literacy is an understanding and set of abilities enabling individuals to recognize when information is needed and can locate, evaluate and use effectively the needed information. Librarians, teachers, technologists, and some policymakers have recently begun to address the need for information literacy training and teaching on all levels of education. In the Norwegian educational sector, governmental units responsible for ICT policies as well as the LIS sector have been preoc- 
cupied with topics and problems falling under the term 'information literacy'. Information literacy as a concept has been formally articulated in the United States since the early 1990s. It appeared as a result of the tremendous progress in information technology and its dramatic impact on information accessibility. Of course, Information literacy is very important for libraries as well as in all areas of life and academic development. Therefore, examining it among management science faculty students is germane.

\section{RELATED STUDIES}

As mentioned in the background, literature has reported some related studies but not focused on Management students' IL competencies. Some of the studies are reviewed as follows. Nwalo and Oyedum (2011) evaluated the IL skills of undergraduate students in six federal universities in Nigeria, particularly on the use of library/ computer literacy. They reported that the IL skills of the students were generally poor. Igwe and Esimokha (2012) assessed the information literacy skills of students at Federal Polytechnic Offa, Kwara State, Nigeria. The study found that students possessed poor information literacy skills, especially in evaluating information resources, citation/referencing, and plagiarism. The absence of an IL course for students, non- integration of IL in the curriculum, the ill-equipped and poor state of resources in the library were identified as factors responsible.

Baro, Seimode, and Godfrey (2013) compared IL practices in university libraries in Nigeria, the UK, and the US, and found that only those in UK and US provide IL training in all the areas; however, there are differences in their IL training delivery methods. Nigerians lacked facilities/understanding of IL due to nonchalant attitude, and low acceptance of the online approach to learning. Ilogho andNkiko (2014) investigated the knowledge of information literacy and search skills of students in five selected private universities in Ogun State, Nigeria. They also examined students' ability to distinguish diverse information sources as well as assess the effectiveness of information literacy programmes. The study concluded that sound information literacy skills are a desideratum in knowledge acquisition in the twenty-first century and recommended that information literacy skills should be integrated into the secondary and tertiary schools' curricula.

A national survey conducted by Lana., and Kaitlyn (2012) identified the skills health paraprofessional students wished to develop after receiving feedback on skill gaps as well as strategies they intended to use to address the gaps. It was discovered that (64\%) of the students intended to develop library skills, while (63\%) intended to developInternet skills and information evaluation skills. Hunn and Rossiter (2006) reported the findings of a project that developed an online information literacy tutori- al at the DCMT Library, Cranfield University. This case study highlighted some of the issues in designing and developing a tutorial for a specific target audience and to describe the actual tutorial package. Discussion on the tutorial design includes commentary on the navigation, themes associated with specific tutorials, and the tools used to engage the user, including a generic search engine.

Igwe and Ndubuisi-Okoh (2014) assessed the level of IL awareness, perception, and skills of students atthe $\mathrm{Na}$ tional Open University of Nigeria. The findings revealed a low level of awareness and poor IL perception arising from the rejection of seven out of ten statements. However, thethree accepted statements see IL issues as an antidote to students' poor IL skills. The IL assessment test shows that more students, when summed together, lack IL skills and recommended integration of IL instruction into the university's curriculum. An exploratory study was conducted by Fong (2014) to determine what librarians in the US are doing to teach research skills to chemistry graduate students. The Chemistry librarians at ARL (Association of Research Libraries) institutions were surveyed about the content they teach; when, where, and how they present it; and what assessment they perform. The results reveal that the most popular resources and information literacy skills taught cover gaps and preferences for teaching and assessment techniques. Ojedokun (2014) conducted a study in some selected universities in Nigeria to determine librarians' information literacy skills. The findings demonstrated that librarians were deficient in the essential skills required for a successful information research process. To remedy the deficiencies, the study recommended regular training and retraining through professional development workshops, librarians' access to, and regular use of the Internet, and the review of the curriculum of library schools.

The review of literature has shown that Information literacy is no longer just a library issue but rather an education and societal issue which has also become a global issue. It could be deduced from the literature that countries around the world are recognizing that only an educated, skilled, and information-literate person can contribute effectively to economic productivity and societal well-being. The literature shows undergraduates are unable to access quality information as well as evaluating the source of information due to their low information literacy skills. It is also evident that students who offer information literacy courses are more successful in utilizing information and this is acquired through the information literacy programmes that the institution curriculum provides. Literature also shows that for undergraduate students to become skilled and information-literate, librarians and faculty at higher education institutions will need to work together as partners to provide the education needed in the age of information. 


\section{METHODOLOGY}

Design: This study was conducted at the University of Ilorin in Ilorin, Kwara State, Nigeria. This study adopted a quantitative survey design. Survey design collects standardized data from large numbers of people. The survey design was considered appropriate in this study as it allows the use of various data collection techniques such as questionnaires, interviews, and observations and to able to generalize the findings of the study to the entire population of management students in the university.

Population and Sample: The target populations of the study were all the full-time undergraduate students in the faculty of management science, the University of Ilorin in the 2017/2018 academic session. As at the time of data collection for the study. the faculty had a total number of three thousand six hundred and thirty -five (3635) students from six different departments: Business Administration, Public Administration, Marketing, Accounting, Finance, Industrial Relations, and Personnel Management. The breakdown of the population is contained in Table 1.

Table 1. Population of The Study

\begin{tabular}{|c|l|c|}
\hline S/N & \multicolumn{1}{|c|}{ Name of Department } & Population \\
\hline 1 & Accounting department & 819 \\
\hline 2 & Finance department & 847 \\
\hline 3 & Business Administration department & 557 \\
\hline 4 & Marketing department & 450 \\
\hline 5 & $\begin{array}{l}\text { Industrial relations and Personal management depart- } \\
\text { ment }\end{array}$ & 553 \\
\hline 6 & Public Administration department & 550 \\
\hline & TOTAL & 3,635 \\
\hline
\end{tabular}

Source: Academic planning office University of Ilorin (2018) and (COMSIT, 2018).

Sample and Sampling Procedure: This study adopted a simple random sampling technique to select the sample from the population. This is to give every respondent in the population an equal opportunity of being selected. Yamane (1967) provided a simplified formula to calculate sample sizes. The author claimed that at a $95 \%$ confidence level, Precision level $=0.05$ can be assumed. The formula is written as $\mathrm{n}=\mathrm{N} /(1+\mathrm{Ne} 2)$. With this formula, the sample size for the study is 360 . The sample size was determined following the equation: $\mathrm{n}=\mathrm{N} /(1+\mathrm{Ne} 2)$, Where $\mathrm{n}=$ the sample size required. $\mathrm{N}=$ total known population of the study, $\mathrm{E}=$ level of significance $=0.05$

$$
\begin{aligned}
& 1=\text { unit }(\text { a constant }) \\
& \mathrm{n}=3635 / 1+3635(0.05) 2 \\
& \mathrm{n}=3635 / 1+3635 \times 0.0025 \\
& \mathrm{n}=3635 / 1+9.09 \\
& \mathrm{n}=3635 / 10.09 \\
& \mathrm{n}=360 \text { (sample size) }
\end{aligned}
$$

\subsection{Data Collection Instruments}

The instrument used for data collection in the study is a questionnaire. As it is known, a questionnaire usually helps to gather the factual-in-depth information. The questionnaire adopted is a closed-ended/structured questionnaire. It was divided into seven sections. Section A requires the respondents' demographic information while Section B-F, was based on the objectives and research questions of the study: Section B focused Students perception of information literacy, Section $C$ focused on Level of Information literacy competence; Section D focused on Strength and weakness in information literacy competence; Section E: focused on Information literacy skills/competence in the retrieval of relevant information; and Section F focused on Information literacy programmes offered by students; while section $\mathrm{G}$ focused on challenges of Information Literacy competence. A four-point rating scale format was used for the items. The responses follow Strongly Agree(SA), Agree(A), Disagree(D), Strongly Disagree(SD).

\subsection{Validity and Reliability of the Instrument}

The instrument was validated to ensure face, content, and construct validity. Content Validity was employed to find if the entire content is relevant to what has been measured. To ensure the face and content validity of the questionnaire, some experts in related research were asked to examine the contents of the questionnaire for language difficulty as well as to determine whether the items contained in the questionnaire are capable of eliciting desired responses. Corrections were made on the questionnaire based on the suggestions by the experts. To achieve the reliability of the instrument used for data collection in the study, a split-half reliability method was used. The instrument was administered to twenty (20) students from different faculties in the university. Responses collected were split into two equal halve and the results were subjected to Cronbach alpha. The overall reliability of the questionnaire returned a reliability coefficient of $r=0.82$. This is considered high enough for data collection as suggested by Guo et al. (2019) and Zhao et al. (2016).

Procedure for Data Collection: At the commencement of the questionnaire administration, respondents were assured of confidentially of the information they provide and were guided on how to complete the filling of the questionnaire. Respondents were allowed to ask questions on any of the items and clear explanationswere provided accordingly. The questionnaire was self-administered to respondents by the researchers. The completed copies of questionnaires were collected for analysis.

Data Analysis Techniques: Collected data on the study were analysed using simple percentages and frequency count. These methods were adopted because of the nature of the data collected. The collected data were coded withthe Statistical Package for Social Science (IBMSPSS) software version 16.0. The results of the analysis were presented in form of tables and figures. 


\section{RESULTS}

A total of 360 copies of the questionnaire were administered to undergraduates of the Faculty of Management Sciences, University of Ilorin; while a total of 337 copies completed the survey giving a response rate of $93.6 \%$. Table 2 provides the details.

Table2. Demography of the Respondents

\begin{tabular}{|l|c|c|}
\hline & Frequency & Percent \\
\hline Gender & & \\
\hline Male & 99 & 29.4 \\
\hline Female & 238 & 70.6 \\
\hline Total & 337 & 100 \\
\hline Department & & \\
\hline Accounting & 47 & 13.9 \\
\hline Business Administration & 72 & 21.4 \\
\hline Finance & 41 & 12.2 \\
\hline Industrial Relation and Personnel Management & 51 & 15.1 \\
\hline Marketing & 70 & 20.8 \\
\hline Public Administration & 56 & 16.6 \\
\hline Total & 337 & 100 \\
\hline Level & & \\
\hline 100 Level & 89 & 26.4 \\
\hline 200 Level & 117 & 34.7 \\
\hline 300 Level & 41 & 12.2 \\
\hline 400 Level & 908 & 26.7 \\
\hline Total & 337 & 100 \\
\hline Age & & \\
\hline 15-20 Years & 114 & 33.8 \\
\hline 21-25 Years & 208.7 \\
\hline 26-30 Years & & 100 \\
\hline & & \\
\hline
\end{tabular}

Table 2 shows that 99 (29.4\%) of the respondents were male while 238 (70.6\%) were female. Hence, the majority of the respondents were female. Also, Table 2 shows 47respondents (13.9\%) were from the Department of Accounting, 72 (21.4\%) were from the Department of Business Administration, 41 (12.2\%) were from the Department of Finance, 52 (15.1\%) were from the Department of Industrial Relation and Personnel Management, 70 (20.8\%) were from the Department of Marketing while 56 (16.6\%) were from the Department of Public Administration. Hence, the majority of the respondents were from the Department of Business Administration. Table.2 further reveals that $89(26.4 \%)$ of the respondents were in 100 level, year 1; 117 (34.7\%) were in 200 level, year 2; 41 (12.2\%) were in 300 level year 3; while 90 (26.7\%) were in 400 level year 4 . This implies that the majority of the respondents were in 200 level. The table also shows that 114 (33.8\%) of the respondents were between $15-20$ years old; 208 (61.7\%) were between 21-25 years old; while 15 (4.5\%) were between $26-30$ years old. Thus, the majority of the respondents were between 21-25 years of age.

Table 3 reveals that 319 (94.7\%) of the respondents agreed that information literacy is a tool for long-life learning while 18 (5.4\%) disagreed; 333 (98.8\%) agreed that In- formation literacy entails knowing when information is needed and being able to calculate the nature and extent of needed information while 4 (1.2\%) disagreed; 330 (97.9\%) agreed that information literacy gives an insight on how to effectively and efficiently access and select needed information while 7 (2.1\%) disagreed; 310 (92.0\%) agreed that information literacy involves evaluating selected information and its source critically while 27 (8.0\%) disagreed; 325 (96.5\%) agreed that information literacy leads to effective use of information to accomplish a specific purpose while 12 (3.6\%) disagreed. This implies that respondents generally perceived IL as an insight on how to effectively and efficiently access and select needed information and as a tool for long-life learning.

Table 3. Student's Perception of Information Literacy

\begin{tabular}{|c|c|c|c|c|c|c|c|c|}
\hline \multicolumn{1}{|c|}{ Items } & \multicolumn{2}{c|}{$\begin{array}{c}\text { Strongly } \\
\text { Agreed }\end{array}$} & \multicolumn{2}{|c|}{ Agreed } & \multicolumn{2}{|c|}{$\begin{array}{c}\text { Disag- } \\
\text { reed }\end{array}$} & $\begin{array}{c}\text { Strongly } \\
\text { Disag- } \\
\text { reed }\end{array}$ \\
\hline $\begin{array}{c}\text { Information literacy is a tool } \\
\text { for long life learning }\end{array}$ & 167 & 49.6 & 152 & 45.1 & 7 & 2.1 & 11 & 3.3 \\
\hline $\begin{array}{c}\text { Information literacy entails } \\
\text { knowing when information is } \\
\text { needed and being able to cal- } \\
\text { culate the nature and extent of } \\
\text { needed information }\end{array}$ & 131 & 38.9 & 202 & 59.9 & 3 & 0.9 & 1 & 0.3 \\
\hline $\begin{array}{c}\text { Information literacy gives an } \\
\text { insight on how to effectively } \\
\text { and efficiently access and sele- } \\
\text { ct the needed information }\end{array}$ & 121 & 35.9 & 209 & 62.0 & 7 & 2.1 & - & - \\
\hline $\begin{array}{c}\text { Information literacy involves } \\
\text { evaluating selected informati- } \\
\text { on and its source critically }\end{array}$ & 96 & 28.5 & 214 & 63.5 & 27 & 8.0 & - & - \\
\hline $\begin{array}{c}\text { Information literacy leads to } \\
\text { effective use of information to } \\
\text { accomplish a specific purpose }\end{array}$ & 166 & 49.3 & 159 & 47.2 & 9 & 2.7 & 3 & 0.9 \\
\hline
\end{tabular}

Table 4. Level of Information Literacy Competence

\begin{tabular}{|c|c|c|c|c|c|c|c|c|}
\hline \multirow[t]{2}{*}{ Items } & \multicolumn{2}{|c|}{$\begin{array}{l}\text { High } \\
\text { Extent }\end{array}$} & \multicolumn{2}{|c|}{$\begin{array}{c}\text { Moderate } \\
\text { Extent }\end{array}$} & \multicolumn{2}{|c|}{$\begin{array}{l}\text { Low } \\
\text { Extent }\end{array}$} & \multicolumn{2}{|c|}{ No Extent } \\
\hline & $\mathrm{F}$ & $\%$ & $\mathrm{~F}$ & $\%$ & $\mathrm{~F}$ & $\%$ & $\mathrm{~F}$ & $\%$ \\
\hline $\begin{array}{l}\text { I can access information } \\
\text { from different sources }\end{array}$ & 181 & 53.7 & 148 & 43.9 & 8 & 2.4 & - & - \\
\hline $\begin{array}{l}\text { I understand when } \\
\text { information is needed } \\
\text { and how to access it }\end{array}$ & 104 & 30.9 & 215 & 63.8 & 16 & 4.7 & 2 & 0.6 \\
\hline $\begin{array}{l}\text { I use the internet to ac- } \\
\text { cess information needed } \\
\text { in my field of study }\end{array}$ & 207 & 61.4 & 98 & 29.1 & 23 & 6.8 & 9 & 2.7 \\
\hline $\begin{array}{l}\text { I can evaluate accessed } \\
\text { information for intelli- } \\
\text { gent decision making }\end{array}$ & 123 & 36.5 & 184 & 54.6 & 28 & 8.3 & 2 & 0.6 \\
\hline $\begin{array}{l}\text { I can use Boolean ope- } \\
\text { ration when searching } \\
\text { for information (AND, } \\
\text { OR, NOT) }\end{array}$ & 41 & 12.2 & 54 & 16.0 & 111 & 32.9 & 131 & 38.9 \\
\hline $\begin{array}{l}\text { I need someone guide to } \\
\text { seek to check informati- } \\
\text { on online and offline }\end{array}$ & 47 & 13.9 & 94 & 27.9 & 85 & 25.2 & 11 & 32.9 \\
\hline
\end{tabular}

Table 4 shows that 181 (53.7\%) of the respondents can access information from different sources to high extent, $148(43.9 \%)$ to moderate extent while $8(2.4 \%)$ to low ex- 
tent; 104 (30.9\%) of the respondents understand when information is needed and how to access it to high extent, $215(63.8 \%)$ to moderate extent, $16(4.7 \%)$ to low extent while $2(0.6 \%)$ to no extent; 207 (61.4\%) of the respondents can use the internet to access information needed in their field of study to high extent, 98 (29.1\%) to moderate extent, 23 (6.8\%) to low extent while 9 (2.7\%) to no extent; 123 (36.5\%) of the respondents can evaluate accessed information for intelligent decision making to high extent, $184(54.6 \%)$ to moderate extent, $28(8.3 \%)$ to low extent while $2(0.6 \%)$ to no extent; 41 (12.2\%) of the respondents can use Boolean operation when searching for information (AND, OR, NOT) to high extent, 54 (16.0\%) to moderate extent, 111 (32.9\%) to low extent while 131 (38.9\%) to no extent; 47 (13.9\%) of the respondents need someone guide to seek to check information online and offline to high extent, 94 (27.9\%) to moderate extent, 85 (25.2\%) to low extent while 11 (32.9\%) to no extent. The result implies that respondents have high IL skills in the use of the internet to access information needed in their field and can assess such information from various sources.

Table 5 reveals that 315 (93.5\%) of the respondents agreed that they can define and calculate the nature and extent of information needed while 22 (6.5\%) disagreed; 316 (93.8\%) of the respondents agreed that they can identify, locate and access sources of information while 21 (6.2\%) disagreed; 299 (88.7\%) of the respondents agreed that they can evaluate information critically and incorporate selected information into knowledge while 38 (11.3\%) disagreed. The three areas of IL strength identified are

Table 5. Areas of Strength in Information Literacy

\begin{tabular}{|c|c|c|c|c|c|c|c|c|}
\hline & \multicolumn{2}{|c|}{$\begin{array}{c}\text { Strongly } \\
\text { Agreed }\end{array}$} & \multicolumn{2}{|c|}{ Agreed } & \multicolumn{2}{|c|}{ Disagreed } & \multicolumn{2}{|c|}{$\begin{array}{c}\text { Strongly } \\
\text { Disagreed }\end{array}$} \\
\hline & $\mathrm{F}$ & $\%$ & $\mathrm{~F}$ & $\%$ & $\mathrm{~F}$ & $\%$ & $\mathrm{~F}$ & $\%$ \\
\hline $\begin{array}{c}\text { I can define and calculate } \\
\text { the nature and extent of } \\
\text { information needed }\end{array}$ & 118 & 35.0 & 197 & 58.5 & 18 & 5.3 & 4 & 1.2 \\
\hline $\begin{array}{c}\text { I can identify, locate and ac- } \\
\text { cess sources of information }\end{array}$ & 122 & 36.2 & 194 & 57.6 & 17 & 5.0 & 4 & 1.2 \\
\hline $\begin{array}{c}\text { I can evaluate information } \\
\text { critically and incorporate } \\
\text { selected information into } \\
\text { knowledge }\end{array}$ & 111 & 32.9 & 188 & 55.8 & 36 & 10.7 & 2 & 0.6 \\
\hline
\end{tabular}

Table 6. Areas of Weakness in Information Literacy

\begin{tabular}{|c|c|c|c|c|c|c|c|c|}
\hline \multirow[t]{2}{*}{ Items } & \multicolumn{2}{|c|}{$\begin{array}{l}\text { Strongly } \\
\text { Agreed }\end{array}$} & \multicolumn{2}{|c|}{ Agreed } & \multicolumn{2}{|c|}{ Disagreed } & \multicolumn{2}{|c|}{$\begin{array}{l}\text { Strongly } \\
\text { Disagreed }\end{array}$} \\
\hline & $\mathrm{F}$ & $\%$ & $\mathrm{~F}$ & $\%$ & $\mathrm{~F}$ & $\%$ & $\mathrm{~F}$ & $\%$ \\
\hline $\begin{array}{l}\text { I can't determine when } \\
\text { information is needed }\end{array}$ & 47 & 13.9 & 69 & 20.5 & 171 & 50.7 & 50 & 14.8 \\
\hline $\begin{array}{l}\text { I am unable to locate and } \\
\text { access sources of information }\end{array}$ & 24 & 7.1 & 74 & 22.0 & 182 & 54.0 & 57 & 16.9 \\
\hline $\begin{array}{l}\text { I am unaware of specific } \\
\text { search strategies e.g. (Boo- } \\
\text { lean Operators, Proximity, } \\
\text { Truncation) }\end{array}$ & 56 & 16.6 & 159 & 47.2 & 103 & 30.6 & 19 & 5.6 \\
\hline $\begin{array}{l}\text { I am unable to evaluate } \\
\text { information critically }\end{array}$ & 23 & 6.8 & 100 & 29.7 & 178 & 52.8 & 36 & 10.7 \\
\hline $\begin{array}{c}\text { I can't use other people's } \\
\text { ethically }\end{array}$ & 35 & 10.4 & 122 & 36.2 & 145 & 43.0 & 35 & 10.4 \\
\hline
\end{tabular}

the ability to defined and circulate information, identify, and access sources of information.

Table 6 reveals that 116 (34.4\%) of the respondents agreed that they can't determine when information is needed while 121 (65.5\%) disagreed; 98 (29.1\%) of the respondents agreed that they are am unable to locate and access sources of information while 139 (70.9\%) disagreed; 215 $(63.8 \%)$ of the respondents agreed that they are unaware of specific search strategies e.g. (Boolean Operators, Proximity, Truncation) while 122 (36.2\%) disagreed; 123 (36.5\%) of the respondents agreed that they are unable to evaluate information critically while 214 (63.5\%) disagreed; 157 (46.6\%) of the respondents agreed that they can't use other people's ethically while 180 (53.4\%) disagreed. The weaknesses identified are inability to determine when information is needed, locatesources, none awareness of specific search engines.

Table 7. Use of Information Literacy Skills in the Retrieval of Relevant Information

\begin{tabular}{|c|c|c|c|c|c|c|c|c|}
\hline Items & \multicolumn{2}{|c|}{$\begin{array}{c}\text { Strongly } \\
\text { Agreed }\end{array}$} & \multicolumn{2}{|c|}{ Agreed } & \multicolumn{2}{|c|}{ Disagreed } & \multicolumn{2}{|c|}{$\begin{array}{c}\text { Strongly } \\
\text { Disagreed }\end{array}$} \\
\hline & $F$ & $\%$ & $F$ & $\%$ & $F$ & $\%$ & $F$ & $\%$ \\
\hline $\begin{array}{c}\text { I can easily use informa- } \\
\text { tion literacy skills to get } \\
\text { information online }\end{array}$ & 188 & 55.8 & 138 & 40.9 & 9 & 2.7 & 2 & 0.6 \\
\hline $\begin{array}{c}\text { I can easily search throu- } \\
\text { gh the library catalogue } \\
\text { to locate information }\end{array}$ & 140 & 41.5 & 180 & 53.4 & 10 & 3.0 & 7 & 2.1 \\
\hline $\begin{array}{c}\text { I can use specific search } \\
\text { term in searching for } \\
\text { information }\end{array}$ & 128 & 38.0 & 187 & 55.5 & 21 & 6.2 & 1 & 0.3 \\
\hline $\begin{array}{c}\text { I can use search engines } \\
\text { to search for informati- } \\
\text { on effectively }\end{array}$ & 161 & 47.8 & 147 & 43.6 & 28 & 8.3 & 1 & 0.3 \\
\hline
\end{tabular}

Table 7 shows that 326 (96.7\%) of the respondents agreed that they can easily use information literacy skills to get information online while 11 (3.3\%) disagreed; 320 (94.9\%) of the respondents agreed that they can easily search through the library catalogue to locate information while 17 (5.1\%) disagreed; 315 (93.5\%) of the respondents agreed that they can use specific search term in searching for information while 23 (6.5\%) disagreed; 308 (91.4\%) of the respondents agreed that they can use search engines to search for information effectively while 29 (8.6\%) disagreed. Respondents can use IL skills to retrieve information, search the library and can use specific search terms

Table 8 reveals that 320 (95.0\%) of the respondents agreed that they can easily use information literacy courses e.g. (introduction to computer application) while 17 (5.1\%) disagreed; 319 (94.6\%) of the respondents agreed that they took part in the course on the use of library e.g. (GNS 102, Effective communication in higher education: the use of library) while 18 (5.3\%) disagreed; 216 (64.1\%) of the respondents agreed that they took part in information technology courses e.g. (GNS 311, Digital skill acqui- 
Table 8. Information Literacy Programme/Courses Offered by Students

\begin{tabular}{|c|c|c|c|c|c|c|c|c|}
\hline \multirow[t]{2}{*}{ Items } & \multicolumn{2}{|c|}{ Strongly Agreed } & \multicolumn{2}{|c|}{ Agreed } & \multicolumn{2}{|c|}{ Disagreed } & \multicolumn{2}{|c|}{ Strongly Disagreed } \\
\hline & $\mathrm{F}$ & $\%$ & $\mathrm{~F}$ & $\%$ & $\mathrm{~F}$ & $\%$ & $\mathrm{~F}$ & $\%$ \\
\hline $\begin{array}{l}\text { Information literacy courses e.g. (introduction to computer } \\
\text { application) }\end{array}$ & 163 & 48.4 & 157 & 46.6 & 13 & 3.9 & 4 & 1.2 \\
\hline $\begin{array}{l}\text { I took part in the course on use of library e.g. (GNS 102, Effecti- } \\
\text { ve communication in higher education: the use of library) }\end{array}$ & 175 & 51.9 & 144 & 42.7 & 18 & 5.3 & - & - \\
\hline $\begin{array}{l}\text { I took part in information technology courses e.g. (GNS 311, Di- } \\
\text { gital skill acquisition, Introduction to information technology) }\end{array}$ & 118 & 35.0 & 98 & 29.1 & 87 & 25.8 & 34 & 10.1 \\
\hline $\begin{array}{l}\text { Information literacy course on effective use of search engine } \\
\text { e.g. (Google, AskMe, Yahoo etc.) }\end{array}$ & 135 & 40.1 & 156 & 46.3 & 34 & 10.1 & 12 & 3.6 \\
\hline $\begin{array}{l}\text { Online Information Literacy Program/Course e.g. (Online Infor- } \\
\text { mation Retrieval, Web design and Management) }\end{array}$ & 108 & 32.0 & 173 & 51.3 & 35 & 10.4 & 21 & 6.2 \\
\hline
\end{tabular}

Table 8. Challenges of Information Literacy Competency

\begin{tabular}{|c|c|c|c|c|c|c|c|c|}
\hline \multirow[t]{2}{*}{ Items } & \multicolumn{2}{|c|}{ Strongly Agreed } & \multicolumn{2}{|c|}{ Agreed } & \multicolumn{2}{|c|}{ Disagreed } & \multicolumn{2}{|c|}{ Strongly Disagreed } \\
\hline & $\mathrm{F}$ & $\%$ & $\mathrm{~F}$ & $\%$ & $\mathrm{~F}$ & $\%$ & $\mathrm{~F}$ & $\%$ \\
\hline $\begin{array}{l}\text { Inadequate time to put information literacy competence into } \\
\text { practice }\end{array}$ & 105 & 31.2 & 199 & 59.1 & 32 & 9.5 & 1 & 0.3 \\
\hline $\begin{array}{l}\text { Epileptic power supply hinder my display of information litera- } \\
\text { cy competence }\end{array}$ & 137 & 40.7 & 171 & 50.7 & 27 & 8.0 & 2 & 0.6 \\
\hline $\begin{array}{l}\text { Lackadaisical Attitude of students affect putting Information } \\
\text { literacy competence into practice }\end{array}$ & 64 & 19.0 & 191 & 56.7 & 69 & 20.5 & 13 & 3.9 \\
\hline High cost of computer gadget and ICT tools & 120 & 35.6 & 177 & 52.5 & 35 & 10.4 & 5 & 1.5 \\
\hline $\begin{array}{l}\text { High cost of data subscription affect my use of information } \\
\text { literacy competence }\end{array}$ & 77 & 22.8 & 174 & 51.6 & 72 & 21.4 & 14 & 4.2 \\
\hline
\end{tabular}

sition), Introduction to information technology) while 121 (35.9\%) disagreed; 291 (86.4\%) of the respondents agreed that they took part in information literacy course On effective use of search engines e.g. (Google, AskMe, Yahoo, etc.) while 46 (13.7\%) disagreed; 281 (86.4\%) of the respondents agreed that they took part in online information literacy program/Course e.g. (online information retrieval, web design, and management) while 56 (16.6\%) disagreed. Prominent information literacy courses offered are the use of libraries, introduction to computers, and IL training on the use of popular search engines such as Google and Ask Me.

On the challenges of information literacy competence, Table 4.7 reveals that $304(90.3 \%)$ of the respondents agreed that there is inadequate time to put information literacy competence into practice, 33 (9.8\%) disagreed; 308 (91.4\%) of the respondents agreed that epileptic power supply hinders students from displaying their information literacy competence, while 29 (8.6\%) disagreed; $155(75.7 \%)$ of the respondents agreed that lackadaisical attitude of students affect putting information literacy competence into practice, while 82 (24.4\%) disagreed; $251(74.4 \%)$ of the respondents agreed that high cost of data subscription affect their usage of information literacy competence while 86 (24.6\%) disagreed. The common factors confronting the teaching of IL at the faculty of management science are power supply, high cost of computers and facilities, and limited time available for hands-on IL skills.

\section{DISCUSSION OF THE FINDINGS}

The finding on the perception of information literacy among the respondents reveals that the respondents generally perceived IL as an insight on how to effectively and efficiently access and select needed information and as a tool for long-life learning. This finding corroborates the description of information literacy by ALA (2007) and Abilock (2004) who looked at information literacy as a transformation process in which the learner needs to find, understand, evaluate and use information in various forms to create for personal, social, or global purposes.IL aims to make information users functional individuals in the world of information instead of been redundant. Therefore, it is not a surprise that the finding on the perception of respondents in this study on IL relates to earlier postulations by ALA and Abilock.

Findings on the level of information literacy competence showed that the majority of respondents have high IL in the use of the internet to access information needed in their field and can assess such information from various sources. This finding is similar to the one by Singh and Joshi (2013) who demonstrated satisfactory along with the significant difference between the first and second-year students and reported high competence in using the internet to access information needed in their field of study and access information from different sources. The similarity in the two studies might be connected with the fact that both studies were conducted focusing on undergraduate students couple with the use of a similar instrument (questionnaire) for the collection of data.

The study reveals three areas of IL strength including circulate information, identify, locate and access sources and evaluate information; while the weaknesses identified are inability to determine when information is need- 
ed, locate and access sources, none awareness of specific search engines, and inability to conduct information evaluation. Nwalo and Oyedun (2011) had earlier reported undergraduate students in their study have poor information literacy skills. Similarly, the finding concurs with Igwe and Esimokha (2012) who reported poor information literacy skills among students of Federal Polytechnic Offa, Kwara State, Nigeria. The finding here is not unexpected because there were bound to be weaknesses in IL skills possessed by the respondents since some factors were identified as confronting the teaching of IL in the faculty. Until such factors are properly taken care of, the IL skills of the respondents might continue to be poor.

CILIP (2005) opined that information literacy is a part of knowledge or learning and is made up of a series of skills or competencies that must be acquired. No wonder the findings in this study revealed information literacy courses offered by the respondents to include how to use the libraries, introduction to computers, and IL training on the use of popular search engines such as Google and Ask Me. This finding is not a coincidence. Graduates from universities nowadays are expected to demonstrate certain IL competencies which in some instance assist in securing jobs. Lack of it may result in a candidate not been preferred by the recruiters. IL skills are needed by every learner irrespective of discipline. No wonder it is now part of the curriculum in most universities.

The common factors confronting the teaching of IL at the faculty of management science are power supply, high cost of computers and facilities, and limited time available for hands-on IL skills. There are peculiarities in developing countries regarding the issue of technology. The teaching of IL and the development of IL skills in school cannot be done in isolation of technology. However, this is bedeviled by issues like cost of the ICT, power outage, and limited-time allotted by some school for IL lessons. This agrees with the earlier findings by authors like Forg (2014) and Ojedokun (2014).

\section{CONCLUSIONS}

Information literacy competence is a crucial skill in the pursuit of knowledge. For students, information literacy skill would lead to independent and student-centric learning, rather than depending on teachers or lecturers to provide answers to questions or problems that they encounter. This will in turn create a greater responsibility toward the individual's learning which will help the students become dynamic learners and thinkers, creative, analytical, and efficient information users. Specifically, this study has shown the information literacy level of the students at the Faculty of Management Sciences, University of Ilorin, Nigeria. It is hereby concluded that there is a high level of information literacy among management science students; however, there are associated challenges that limit the teaching of the course.

\subsection{Recommendations}

Based on the findings of this study and the conclusion, the following recommendations are made:

1. The university management should introduce an information literacy course as a compulsory course for all the students.

2.Practicals/Hands-on on IL skills should be introduced and also be made compulsory for the students.

3. The inability to determine when information is needed, none awareness of specific search engines should be more focused on the IL literacy programme.

4. The authority should see to the challenges confronting the teaching of IL in the faculty including power supply, high cost of computers, and limited time available for IL practical and hands-on. In light of these, the university should consider providing alternative power generating machines to substitute for electricity. They should also consider distributing computers to the students either free or by payment of some token. This will facilitate the teaching of IL. Lastly, more time should be allotted to the teaching of IL to accommodate some important hands-on that can lead to the development of necessary IL skills by the students.

\subsection{Limitation of the Study and Suggestions}

The study focused on the information literacy competence of management science students at the University of Ilorin, Nigeria. This is considered a limitation. Therefore, a related study should be conducted that extends the scope of the study to cover the entire university or beyond. A self-reported instrument, a questionnaire was used for the collection of data. Future research should consider collecting data using other methods including interviews, observation, and document analysis.

\section{REFERENCES}

Abilock, D. (2004). Information literacy: an overview of design, process, and outcomes. Accessedon 12 April 2012 http://www.noodletools.com/debbie/literacies/information/1over/infolit1.html

American Library Association (ALA). (2007). Retrieved August 04, 2014, from http://www.ala.org/acrl/standards/informationliteracycompetency

ALA, (2000). Information Literacy Competency Standards for Higher Education (available at:http://www.ala.org/acrl/ standards/informationliteracycompetency(Accessed 14 January 2018).

ALA (1989). National Forum on Information Literacy 1999-2000 Report. Retrieved http://www.ala.org/aboutala/national-forum-information-literacy-1999\%E2\%80\%932000-report (accessed 31 August 2020).

Association of College and Research Libraries. (2014). Framework for Information Literacy for Higher Education. Association of College and Research Libraries, last modified 
February 20, 2014, Accessed April 2.

Baro E E, Seimode F D. \& Godfrey, V Z. (2013). Information Literacy Programmes in University Libraries: a case study. Libri 63(4), 282-294.

Baskaran, S. Ramesh, B. \&Golpakrishnan, S. (2011). Information skills of library and Information science (LIS) students of Karnataka state: a survey. In Ramesha\&Shivarama (Eds.), InformationLiteracy and Higher Education in Digital Environment (Proceedings of the National Conference, Karnataka State Open University, Mysore, India, 2011) (pp. 13 -20). Mysore: KSOU

Brettlea, A. \& Raynor, M (2011). Developing information literacy skills in pre-registration nurses: An experimental study of teaching methods, Nurse Education Today. Elsevier Ltd.

CILIP. (2005). Information Literacy: definition. Chartered Institute of Library and Information Professionals. Retrieved June 10, 2013, from http://www.cilip.org.uk/getinvolved/ advocacy/informationliteracy/pages/definition.aspx

Council of Australian University Librarians (CAUL) (2004). Information Literacy Standards. 1st Ed. Canberra: CAUL, 2001. http://www.anu.edu.au/caul/cauldoc/InfoLitStandards2001.doc

European Commission (2007). The key competences for lifelong learning - a European framework. Luxembourg: Office for Official Publications of the European Communities. [online]. http://ec.europa.eu/dgs/education_culture/publ/ pdf/ll-learning/keycomp_en.pdf

Fong, B. L. (2014). Searching for the formula: how librarians teach chemistry graduate students research skills, Issues in science and technology librarianship, 75. Retrieved August 9, 2017, from http://www.istl.org/14-winter/refereed1.html

Guo, Y., Sun, Y., Li, L., Longbiao Li \&Xiaoming Tang. (2019). Reliability assessment for multi-source data of mechanical parts of civil aircraft based on the model. Journal of Mechanical Science Technology, 33, 3205-3211. https://doi. org/10.1007/s12206-019- 0615-4

Hunn, R. A., \& Rossiter, D. (2006). Design and development of an online information literacy tutorial: evaluation and lessons learnt (Case Study), DCMT Library, Cranfield University. Retrieved September 10, 2013, from http://journals. heacademy.ac.uk/doi/pdf/10.11120/ital.2006.0504018457.

Igwe,K.N. \&Esimohka, G. A. (2012). A Survey of the Information Literacy Skills of Students of Federal Polytechnic Offa, Kwara State, Nigeria. The Information Technologist: InternationalJournal of ICT, 9 (2), 9 - 19.

Igwe, K.N \& Ndubuisi-Okoh, E.O. (2014). Information literacy awareness, perception and skills assessment using students of national open university in Southwest Nigeria. International Journal of Digital Literacy and Digital Competence 5(3), 15 - 29. DOI: 10.4018/ijdldc.2014070102

Ilogho, J. E., \&Nkiko, C. (2014). Information literacy search skills of students in five selected private Universities in Ogun State, Nigeria: a survey, Library Philosophy and Practice (e-Journal), Paper 1040. Retrieved August 9, 2014, from http://digitalcommons.unl.edu/libphilprac/1040

International Federation of Library Associations and Institutions (IFLA). (2000) Beacons of the Information Society. Retrieved February 15th, 2012 from http://www.ifla.org/ III/wsis/Bea conlnfSoc.html
Lana , V.,\& Kaitlyn A. H. (2012). Developing health information literacy: a needs analysis from the perspective of preprofessional health students. Journal of the Medical Library Association. , 100(4), 277-283.

Lupton, M. (2004). The learning connection. Adelaide: AusLib Press.

Nwalo K I N and Oyedum G U, Relationship of information literacy to undergraduate students' use of university libraries. Library Progress International, 31 (2) (2011) 347-362.

OECD (2005). The definition and selection of key competencies: executive summary. Paris: OECD. [online]. http:// www.pedagogy.ir/images/pdf/key-competencies-oecd05. pdf

Ojedokun, A.A. (2007). Information Literacy for Tertiary Education Students in Africa, (Ibadan; Third World Information Services Ltd).

Ojedokun, A. A. (2014). Information literacy competence of librarians in South West Nigerian university libraries. African Journal of Library Archives and Information Science, 24 (1), 67-90.

Singh,D. \& Joshi, M.K. (2013).Information literacy competency of postgraduate students at Haryana Agricultural University and the impact of instruction initiatives: A pilot survey. Reference Services Review, 41(30), 453-473.

Yamane, T. (1967). Statistics, An Introductory Analysis, 2nd Ed., New York: Harper and Row.

Zhao, J.Y., Sun, G.Q., Zeng, S.K., Guo., J.B., \& Zhou, G. (2016). The reliability assessment of human systems interaction for aircraft carrier landing. Journal of Mechanical Science and Technology, 30 (10),4465-4469.

Zurkowsky, P.G. (1974). The Information Service Environment Relationships and Priorities. Related Paper .5. 